\title{
Giovanni Pico della Mirandola: De genere dicendi philosophorum
}

\section{Prevod Blaž Ploj}

Junija 1485 je Giovanni Pico della Mirandola, tedaj še študent, Ermolau Barbaru, zagrizenemu humanistu in ostremu kritiku »barbarskih« filozofov, na njegovo zadnje pisanje odgovoril s pismom, $\mathrm{v}$ katerem je na duhovit način obravnaval odnos med retoriko in filozofijo. V njem si je zamislil sholastičnega filozofa, ki ga je opremil z izostrenim občutkom za jezik ter najširšo humanistično izobrazbo in mu odstopil glavni del pisma, da bi lahko kar se da spretno odgovoril na ostre očitke, ki jih je na račun njega in njegovih kolegov v svojem zadnjem pismu izrekel Barbaro.

Korespondenca med Barbarom in Picom predstavlja epizodo v polemiki, ki so jo humanisti vodili proti sholastičnim filozofom. Očitali so jim, da so latinski jezik iznakazili do nerazpoznavnosti, ga "pobarbarili« in s tem onemogočili pravo humanitas. Šlo je za ideološko opredeljevanje humanistov do svoje neposredne preteklosti, "temnega" srednjega veka, in do antike, v kateri so videli svetli vir neokrnjene modrosti. Ne sme čuditi, da so se pri tem osredotočali na jezik, natančneje na leksiko in slog, saj je temelje humanizma - izobraževalnega in kulturnega programa, na katerem je temeljila renesansa - tvorilo gramatično, retorično in literarno udejstvovanje. Pico je s svojim pismom napravil rez v humanistično polemiko proti filozofom in namišljenemu sholastiku omogočil, da je tok kritike in očitkov obrnil proti humanističnim zagovornikom elegantnega izraza ter da se je zavzel za svojo disciplino.

Pismo predstavlja dragocen dokument, ki natančno priča o dogajanju na renesančnem intelektualnem polju v drugi polovici 15. stoletja. To je čas nekaterih najznačilnejših in najzanimivejši renesančnih filozofskih konceptov in iz pisma je mogoče razbrati elemente, ki so pomembno prispevali $\mathrm{k}$ njihovemu razvoju. Zagovor sholastika je Pico na osnovi Platonove kritike govorništva napisal v visoko izdelanem retoričnem slogu, s čimer je v pismu združil tri miselne tokove, ki so imeli v Italiji poznega 15. stoletja dominan- 
ten vpliv na razvoj filozofske misli in kulture nasploh - humanizem, univerzitetni aristotelizem in platonizem. Pico se je z vsemi dodobra seznanil in kmalu jih je, ko je njegov nenasitni eklekticizem segel še po orientalski vednosti, združil v svojih središčnih filozofskih konceptih: univerzalnosti ene večne resnice, ki se odseva v stvarstvu, slogi vseh filozofij in religij ter človekovem dostojanstvu. S pismom, ki se ga je kasneje prijel naslov De genere dicendi philosophorum, kot ga je v svojem odgovoru poimenoval Barbaro, je mladi mislec prvič stopil na renesančno kulturno sceno. $Z$ njim je nakazal pot, po kateri bo stopal z nekaterimi svojimi sodobniki, s katerimi je proti koncu 15. stoletja od pedantnega poudarjanja jezikovne forme zakorakal proti zavzetemu preučevanju filozofske in teološke materije.

Prevod pisma je nastal po izvirniku iz komentirane izdaje Ermolao Barbaro, Giovanni Pico della Mirandola: Filosofia o eloquenza? izd. Francesco Bausi (Neapelj, 1998), od koder je prevzeta tudi numeracija pisma.

\section{GIOVANNI PICO DELLA MIRANDOLA SVOJEMU ERMOLAU BARBARU POZDRAV}

[1] Resnično ne morem tajiti svojih čustev do tebe, moj Ermolao, niti si ne morem predstavljati, da do tebe ne bi čutil tega, kar dolgujemo človeku, ki kaže prav vse najvišje vrline. [2] O da bi moje srce premoglo čustva, ki si jih tvoja dejanja zaslužijo; o da bi moje besede premogle tolikšno izrazno moč, da bi kdaj mogel povedati, kako že od nekdaj čutim do tebe. [3] Vem, da bo to, kar mislim o tebi, večno zasidrano pod vrhovi tvoje učenosti. [4] Tudi ti veš, da je vse, kar izrečemo, dosti nižje od tega, kar mislimo; veš, da tako besede ne morejo obseči duha, kakor duh ne more obseči resničnosti. [5] In vendar verjameš, da si drznem upati, da bi lahko tvoja dela posnemal, čeprav njihove veličine niti premeriti ne morem! [6] Občudujejo te lahko vsi, posnemajo le maloštevilni, nihče pa te ne more doseči. [7] Ko bi le imel to srečo, da bi v pisanju vsaj deloma posnemal dragega Ermolaa! [8] Prav čudovito je namreč, če ostalo zamolčim, kako me že sam tvoj slog, ki ga ti odločno premalo hvališ, ${ }^{1}$ prevzema in razveseljuje, tako je učen, prepričljiv, uravnotežen, izglajen in bistroumen. [9] V njem ni nič nizkotnega, nič obrabljenega, nič prostaškega, najsi gledaš besede ali celotne periode. [10] Jaz in naš Poliziano pogosto bereva tvoja pisma, naslovljena bodisi na naju bodi na druge, da nama le pridejo v roke. Novejša se venomer kosajo s starejšimi. Med branjem pred

1 Barbaro je nezadovoljstvo nad svojim slogom pisanja izrazil v pismu Picu, datiranem na 5. april 1984 (Barbaro, Epistolae 68: Barbarova pisma navajam po Ermolao Barbaro: Epistolae, orationes et carmina, izd. Vittore Branca, Firence: Bibliopolis, 1943), na katerega je Pico odgovoril s tem pismom, in v enem od uvodnih pisem k svojemu prevodu Temistija, naslovljenem na Giorgia Merulo (Barbaro, Epistolae 10). Mogoče je, da je šlo za resnično in iskreno nezadovoljstvo z lastnim slogom, a bolj verjetno se zdi, da je šlo za hlinjeno skromnost, ki skupaj s hvalilnimi formulami, ki so bile namenjene laskanju naslovniku, tvori eno od ključnih sestavin humanistične korespondence. 
nama vzcveti toliko razkošne lepote, da nama od očaranosti zastaja dih. [11] In kako čudovito moč ima tvoja prepričljivost, da bralčevega duha z lahkoto pahneš, kamorkoli te je volja. ${ }^{2}$ [12] Sam sem to izkusil, kakor zmeraj doslej, tudi v zadnjem pismu, ki si mi ga poslal. Medtem ko sem bral, kako zaničuješ te barbarske filozofe, o katerih praviš, da se jih množično razglaša za nizkotne, surove in neomikane, da niso živeli niti za časa svojega življenja, kaj šele da bi živeli po smrti in da bi živeli zaničevani ter v sramoti, če bi živeli še danes, ${ }^{3}$ sem bil tako pretresen, pri Herkulu, tako sem se sramoval in kesal svojih študijskih prizadevanj (že šet let namreč se mudim z njimi), ${ }^{4}$ da si nisem želel ničesar manj, kakor tako vztrajno ubadati se s tako nepomembno stvarjo. [13] Povem ti, ob delih Tomaža, Janeza Skota, Alberta in Averroesa ${ }^{5}$ sem zapravil najboljša leta in prebedel številne noči, ki bi jih lahko posvetil lepi književnosti. [14] Da bi se potolažil, sem si skušal predstavljati, ali bi ti sicer ostroumni možje, če bi nekateri od njih zdaj oživeli, zmogli razumno zagovarjati svoj primer. [15] Naposled sem si zamislil enega od njih, nekoliko spretnejšega govorca, ki bi svojo barbarskost, kolikor nebarbarsko bi pač mogel, morebiti branil takole:

[16] »Živeli smo slavni, o Ermolao, in tudi poslej bomo živeli, vendar ne $\mathrm{v}$ deških šolah, temveč ob omizjih filozofov in v zborih modrecev, kjer se ne razpravlja o materi Andromahe in Niobinih otrocih ter o te vrste lahkotnih igračkah, ${ }^{6}$ temveč se preudarja in tehta zakonitosti človeških ter božjih zadev. [17] Med tuhtanjem, raziskovanjem in pojasnjevanjem le-teh smo bili tako prefinjeni, ostroumni in natančni, da smo se morda kdaj zdeli preveč previdni v sodbah in dlakocepski, če je sploh kdo lahko preveč natančen ali dlakocepski pri preučevanju resnice. [18] In če nas zaradi tega kdo dolži topoglavosti in počasnosti, naj kar pristopi, kdorsibodi, v veselje mi bo: spoznal bo, da barbari Merkurja ${ }^{8}$ nimajo na jeziku, ampak v srcu ${ }^{9}$ in da jim ne manjka modrosti, če jim manjka govorniška spretnost, ki jo je približno tako nedol-

\footnotetext{
Prim. Kvintilijan, Insitutio oratoria 2.15.10; Platon, Phaedrus 261a in 271c.

Prim. Petrarca, Familiares 1.2.18 in Seniles 5.2; Erazem Rotterdamski, Moriae encomium 37.

Od leta 1480, ko je na Univerzi v Padovi začel študirati filozofijo.

5 Predstavniki sholastike oz. srednjeveškega aristotelizma. Pico se v nadaljevanju pisma vrne $\mathrm{k}$ Janezu Skotu ( $\$ \$ 126-134)$, saj je ta med humanisti veljal za prvaka in model barbarske srednjeveške lingvistike ter sholastičnega »dlakocepstva« (glej npr. Erazem Rotterdamski, Moriae encomium 53 in 63).

6 Prim. Tacit, Dialogus de oratoribus 31.1; Pico se tukaj opre na Seneko, ki v 88. pismu Luciliju (2-4) zapiše, da za filozofa ni dovolj, da je seznanjen s svobodnimi umetnostmi (v tem odlomku je izpostavljena grammatica), saj te same človeka še ne naredijo krepostnega. Filozof naj jih sicer pozna, a pri njih naj se ne zadržuje predolgo. V istem Senekovem pismu (6-7 in 37) najdemo tudi veliko primerov t.i. leves nugae ali lahkotnih igračk, vaj študentov govorništva, med katere spadajo tudi debate o številu Niobinih otrok, ki so ga antični avtorji različno ocenjujevali: glej npr. Apolodor, Bibliotheca 3.5.6 in Gelij 20.7.

7 Prim. Cicero, De oratore 1.49.

8 Merkur je bil med drugim bog govorniške spretnosti, v srednjem veku pa je simboliziral dejavnosti človeškega razuma in veljal za posrednika med človeško in božansko modrostjo.

9 Jezik in srce sta metafori za govornika in filozofa. Antiteza se v pismu pojavi še v $\$ 119$. Prim. $\$$ 68.
} 
žno ločevati od modrosti, kot jo je z njo nedopustno združevati. ${ }^{10}[19]$ Kdo namreč ne bi obsojal lišpa in lepotil ${ }^{11}$ na vrli devici? ${ }^{12}$ [20] In kdo jih na vestalki ne bi preklinjal? ${ }^{13}$ [21] Nasprotovanje med poslom govornika in dejavnostjo filozofa je tako veliko, da si bolj v nasprotju ne bi mogla biti. [22] Kajti kaj drugega je posel govornika kot lagati, zavajati, varati in zapeljevati? ${ }^{14}$ [23] V vaši moči je namreč, kot pravite, da po želji črno spremenite v belo in belo v črno; da karkoli želite, $z$ besedami povečate, zavržete, pomnožite, pomanjšate; ${ }^{15}$ in naposled da $z$ nekakšnimi čarobnimi močmi govorništva, ${ }^{16}$ kot se bahate, samim stvarem poljubno spreminjate videz in lastnosti, tako da se poslušalcem ne kažejo, kakršne so po svoji naravi, temveč kakršne so po vaši volji, ${ }^{17}$ in ne le, da se spremenijo, ampak se kažejo tam, kjer jih ni. [24] Ali je to, kar naravo stvari venomer ali presega zaradi poveličevanja ali je ne dosega zaradi pomanjševanja, kaj drugega kot čista prevara, čista sleparija, čista goljufija; kar se ponaša z varljivim sozvočjem besed, kot prikazni in prividi, ter s prilizovanjem zapeljuje misli poslušalcev? [25] Je v tem kakšna podobnost s filozofom, ki z vso vnemo stremi po spoznavanju in razlaganju resnice?

[26] Dodati je treba, da si verodostojnosti ne bomo prislužili s prizadevanjem po veličastnem in mikavnem izrazu, kakor če bi hoteli brez zaupanja $\mathrm{v}$ stvarnost in brez opore $\mathrm{v}$ resničnosti ljudi prepričati s prilizovanjem. [27] Zato je svete zadeve bolje brati v preprostem jeziku kot elegantno spisane, saj v celotnem gradivu, ki govori o spoznavanju resničnosti, ni nič bolj neprimernega in škodljivega kot ves ta izumetničen slog govora. [28] To je stvar sodnih, ne naravnih in nebeških vprašanj; ${ }^{18}$ to ni stvar tistih, ki se mudijo v Akademiji, ${ }^{19}$ ampak tistih, ki so dejavni v politiki, kjer se vsa dejanja

10 Humanisti so bili mnenja, da je tudi v filozofskih delih potrebno uporabljati latinščino po zgledu avtorjev klasične dobe latinske književnosti. Barbaro je v uvodnem pismu k Temistiju, naslovljenem na Siksta VI. (Barbaro, Epistolae 8), zapisal: »... ko rečem književnost, mislim na filozofijo, ki naj bo združena $\mathrm{z}$ govorniško spretnostjo."

11 Prim. Cicero, De oratore 3.25 in Platon, Gorgias 463b, kjer Platon govorništvo med drugim primerja s kozmetiko in oboje označi za prilizovanje (ne veščino), ki služi za izigravanje in zapeljevanje nevednih ljudi z lažnim videzom.

12 Primerjava filozofije s čisto, vrlo devico je prevzeta iz Cicero, Orator 19.64.

13 Vestalkam je bila zapovedana stroga čistost, njihova obleka je bilo preprosto laneno oblačilo starinskega kroja. Livij opisuje primer, ko so eno izmed njih živo zakopali, ker se je oblekla preveč elegantno (Livij 8.15.7-8). Plinij Mlajši priča o enaki kazni za vestalko, ki jo je Domicijan obsodil spolnega občevanja (Plinij, Epistulae 4.11).

14 Prim. Platon, Gorgias 454e-455a in 459a-c.

15 Retorični postopki: prim. Aristotel, Rhetorica. 2.26.1-2 in 2.24.4; Kvintilijan, Insitutio oratoria 8.4.1-3; Platon, Phaderus 267a.

16 Prim. Platon, Euthydemus 289e.

17 Prim. Platon, Phaedrus 261c-d.

18 Prim. Platon, Theaetetus 173d-e. O tem, da je mesto govorništva na sodiščih, javnih zborovanjih in shodih: Platon, Gorgias 454e, 500 in Phaedrus 268a; Barbaro, De coelibatu 4.2: "Kdo pa ne bi vedel, da raba govorniške spretnosti stremi po upravljanju javnih zadev, ne po samotnem in svetlobe boječem življenju?«

19 Hieronim pripoveduje, da je Platon svojo šolo ustanovil v vasi Accademia, ki je bila daleč od Aten, pusta in izpostavljena nezdravemu vremenu, ter da je tako dosegel, da so njegovi učenci zaradi oddaljenosti mestega vrveža in zaradi nenehne grožnje bolezni pozabili na naslado in se popolnoma posvetili študiju (Hieronim, Adversus Jovinianum 2.9). 
in besede polaga na ljudsko tehtnico, na kateri ima cvetje dosti večjo težo kakor sadovi. [29] Ali ne poznaš tistega izreka? [30] »Ne pristoji vsakomur, kar je spleteno na enak način. « $^{20}[31]$ Govorniška spretnost, vabljiva in mikavna, je imenitna stvar (to priznamo), a za filozofa ni niti spodobna niti primerna. [32] Le kdo ne bi hvalil poskočnega koraka, gibkih rok in igrivega pogleda pri glumaču in plesalcu. ${ }^{21}$ [33] In kdo jih pri državljanu ter filozofu ne bi zavračal, grajal in preziral? [34] Če bomo videli duhovito in jezično dekle jo bomo hvalili in ji laskali; pri poročeni dami bomo to obsojali in kaznovali. ${ }^{22}$ [35] Nismo torej mi nespodobni, ampak oni, ki ob nogah Veste slavijo bakhanalije $^{23}$ in ki dostojanstvenost ter čistost filozofskih zadev skrunijo z besednim igračkanjem in izumetničenostjo. [36] Gotovo bi Sinezijeve ${ }^{24}$ trditve o mladeničih lahko prenesli tudi na način izražanja: bújnost sloga vedno kaže na razuzdanost. ${ }^{25}$ [37] Zato imamo raje, da je naša govorica neurejena, robata in zapletena kakor olepšana $\mathrm{z}$ noto nečednosti ali slutnjo nečistosti. [38] Takšna ne le, da ne bi razgrnila Ateninega pepla, ampak bi bila kot nečista izključena od svetih obredov. ${ }^{26}$

[39] In četudi je vse ostalo brez pomena, to vendar drži kot pribito, namreč da drži filozofa ni nič bolj tuje kakor kakršnokoli pečanje z razkošjem in bliščem. [40] Sokrat ${ }^{27}$ je pravil, da so sikionijski čevlji sicer udobni in da

20 V izvirniku: „Non omnia omnibus pari filo conveniunt.« Gre za citat Barbarovega prevoda Temistijevih Parafraz (Brabaro Ermolao, izd. Themistii Paraphrasis in Aristotelem. Benetke: Bartolomeo Zani, 1499: 73v). Prim. Lukrecij 2.340-341. Pico se poigra z večplastnim pomenom besede filum (nit, preja, tkanina, oblika, podoba, postava in metaf., v vezi z govorom, način, značaj, vrsta, slog). Primerjava sloga izražanja z oblačili tudi v Petrarca, Familiares 22.2.

21 Prim. Gelij 1.5.2-3 in 3.5.2; Cicero, De oratore 3.59 in De finibus 3.7; Kvintilijan, Institutio oratoria. 11.3.89.

22 Prim. Platon, Gorgias $485 \mathrm{~b}-\mathrm{c}$.

23 Prim. Juvenal 2.3. Pico filozofijo zaradi čistosti (neizumetničenosti) primerja z Vesto.

24 Sinezij iz Kirene (ok. 370-ok. 414), škof Ptolemaide, avtor 156 pisem, 9 himn v klasičnih oblikah in več razprav. V spisu Dio (naslovljenem po Dionu Hrizostomu) se distancira od brezvsebinske, prazne retorike in nekulturnosti menihov.

25 Pico se tukaj sklicuje na Sinezij, Epistulae 104. Glej tudi Sinezijev govor Hvalnica plešavosti (Calvitii encomium), humoristični retorični odgovor na Dionovo (v Sinezijevi Hvalnici delno ohranjeno) Hvalnico las. Za topos primerjave urejenega videza in izumetničenega izraza ter povezanosti obojega z razuzdanostjo oz. pomehkuženostjo glej npr. Seneka, Epistulae 114 in dialoge Lukijana iz Samosate: Rhetorum praeceptor, Bis accusatus, Pseudologista, Anacharsis, Scytha.

26 Pico tukaj meri na sveti obred, v katerem so ženske kip Atene ogrnile v bogato izvezen peplos (Homer, Ilias 6.286-310; Vergilij, Aeneis 1.479-82; Ciris 21-41; v Stacij, Thebais. 10.56-69 peplos darujejo Junoni). Obred je bil del starodavnega atenskega praznika panatenaje, ki so ga praznovali v čast rojstva boginje Atene. Vrhunec praznovanja je bil veličasten sprevod, ki se je vil po Panatenajski cesti do Partenona, kjer so do Ateninega kipa prinesli njeno novo oblačilo, peplos, ki so ga stkale Atenke iz bogatih in plemenitih družin. Peplos so peljali na veliki ladji na kolesih, za njo so hodila dekleta - morala so biti neomadeževana -, ki so na glavah nosila košare z žrtvenimi darili. Tukidid poroča, da je bila velika sramota, če so dekle zavrnili kot neprimerno, kar se je zgodilo Harmodijevi sestri, ki jo je odklonil Hiparh. Odklonitev naj bi bila po Tukididovem poročanju povod za Hiparhov umor, ki sta ga na panatenajskem sprevodu izvedla užaljeni Harmodij in Aristogejton (Tukidid 6.56.1-2). Pico slog filozofov primerja z ženami - biti so morale odrasle, poročene in z otroki -, ki so peplos prinesle k Ateninemu kipu (tako kot Vesta je tudi Atena veljala za nravno in čisto boginjo), ter neomadeževanimi, čistimi dekleti, ki so sodelovala v sprevodu. Vergilij poroča, da so žene obred opravljale spuščenih las (Vergilij, Aeneis 1.480).

27 Pico v pismu Sokrata navaja kot zgled zmernega in načelnega življenja ter preprostega in jasnega izražanja. V na novo odkritih Platonovih delih je lahko prebiral, kako se je Sokrat v dialogih zo- 
se lepo nosijo, vendar da Sokratu ne pristojijo. ${ }^{28}$ [41] Oprava navadnega državljana in filozofa je popolnoma drugačna, kakor tudi njuna jed in njun govor. Filozof vse to koristi, kot mu narekuje potreba, navadni državljan pa tudi, da si pridobi naklonjenost. Če se slednji zanjo ne bi zmenil, ne bi bil navadni državljan in če bi si jo prvi skušal pridobiti, ne bi bil filozof. [42] Ko bi Pitagora ${ }^{29}$ lahko živel brez hrane, bi se še zelju odrekel;30 ko bi svoje misli lahko razložil s pogledom ali s čim, kar terja manj truda kot govor, sploh ne bi govoril, ${ }^{31}$ tako malo si je prizadeval za izpiljen in bogat jezik. [43] Zaradi tega moramo paziti tudi, da se bralec, ki ga je zapeljala nališpana zunanjost, pri njej ne bi ustavil, saj tako ne bi prodrl do mozga in krvi, ${ }^{32}$ pri kateri vidimo, da je zaradi ličil pogosto okužena. [44] Videli smo, pravim, pri vseh teh, ki jim je to prišlo v navado, da ko nimajo ponuditi nič razen praznine in puhlosti, bralca $\mathrm{z}$ melodičnim in umerjenim zvenom besed zadržujejo pri zunanjosti. ${ }^{33}$ Če bi to storil filozof, bi Muzonij zaklical, da ne govori filozof, ampak da svirač igra na piščal. ${ }^{34}$ [45] Zatorej naj se nam ne šteje v pregreho, da smo se vzdržali takšnega početja, ker bi prav takšno početje bilo pregrešno. [46] Za nas je pomembno, kaj pišemo in ne, kako pišemo; ali raje, pomembno je tudi kako. Vsekakor brez blišča in okrasja besed, za katere nočemo, da so všečne, ljubke in lične, temveč uporabne, tehtne in častivredne, naj raje z grobostjo dosežejo veličino, kakor da si z mehkobo pridobijo hvalo. [47] Ne potrebujemo aplavza občinstva, ki navdušeno ploska, ker je ušesa pobožala pravomerna ali ubrana poved in ker je to duhovito, tisto očarljivo, ampak pričakujemo občudovalno tišino maloštevilnih, ki natanko in temeljito motrijo nekaj, kar je bilo iztrgano iz svetišč narave ali kar je bilo ljudem prinešeno z dvora nebeščanov in Jupitra; ${ }^{35}$ morda tudi nekaj, kar je tako jasno, da je pojasnjevanje ne-

perstavljal sofistom oz. retorjem in njihovi dejavnosti, kar se je ujemalo z vsebino zagovora, ki ga je položil v usta namišljenemu sholastiku. V skladu s Picovimi idejami o skupnem, božanskem

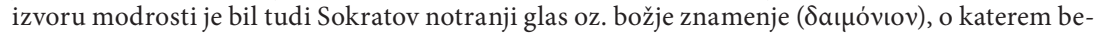
remo v Platon, Apologia 40a-b, ki naj bi mu preprečevalo, da bi storil kaj napačnega.

28 Glej Cicero, De oratore 1.54 in Diogen Laertski, Socrates 40-41. Ksenofont piše, da je Sokrat hodil bos (Ksenofont, Memorabilia 1.6.2). Pri Lukijanu (Lukijan, Rhetorum Praeceptor 15) učitelj govorništva svojim učencem svetuje, naj nosijo svetle, vpadljive barve ali belo, obujejo pa naj obutev atiške ženske oblike ali sikionijske čevlje.

29 Pitagora v pismu enako kot Sokrat predstavlja zgled zmernosti, kreposti in modrosti. V skladu s Picovo doktrino in hkrati v soglasju z zagovorom namišljenega sholastika je bilo pitagorejsko načelo, da modrost ni namenjena neposvečenim oz. ljudskim množicam.V naukih pitagorejcev je Pico lahko našel tudi nauk o modrosti oz. spoznanju, ki človeka naredi božanskega, o čemer piše v svojem Oratio de hominis dignitate ( $\mathrm{O}$ človekovem dostojanstvu).

30 Bil je vegetarijanec, isto je zapovedoval tudi svojim učencem. Želodec je bil po njegovem nauku nasprotnik duše in če je bil prepoln, je dušo obtežil in jo oviral.

31 Molk je spadal med njegove glavne zapovedi. Prim. Seneka, Epistulae 75.2.

32 Prim. Gelij 18.4.2 in 8.4.6.

33 Pico je tega obtožil Petrarco v pismu Lorenzu Medičejskemu z datacijo 15. julij 1484.

34 Muzonij je bil slavni stoiški filozof, učitej Epikteta in Diona Hrizostoma. Njegovo izjavo je Pico povzel po Geliju, 5.1.1.

35 Namig na Prometeja, ki ga tradicija opisuje kot modreca, ogenj pa interpretira kot alegorijo za dušo, krepost, razum in spoznanje. Po Jamblihu (Vita Pythagorica 30) se Prometeju zelo približa Pitagora - Jamblih poroča, da naj bi po mnenju nekaterih bil bog, ki je prišel na zemljo v človeški podobi, da bi smrti zapisanim ljudem uredil življenje in jim prinesel zdravilno iskro sreče in filozofije. 
potrebno ali kar je tako neovrgljivo, da dokazovanje ni potrebno. [48] Naj razen tega občudujejo, kako natančni smo pri preiskovanju in kako premišljeni pri poizvedovanju; kako tenkočutni smo pri opazovanju in kako preudarni v razsojanju; kako spretno spletamo in s kakšno lahkoto razpletamo. [49] Občudujejo naj našo slogovno jedrnatost, ki jo oplajajo mnoge velike reči; najgloblje misli, skrite pod jasnimi besedami, polne vprašanj in polne razlag. Našo spretnost in podkovanost v odpravljanju dvoumnosti, preganjanu dvoma, razpletanju zapletenih primerov, izpodbijanju zmot in potrjevanju pravilnega $z$ dušepremičnimi silogizmi. ${ }^{36}$

[50] S takšnim slovesom, o Ermolao, smo do sedaj in nedvomno bomo tudi v prihodnje spomin na nas rešili pred pozabo. [51] In če se nas že množično razglaša, kot praviš, za nizkotne, surove in neomikane, nam je to v čast in ne v sramoto. [52] Nismo pisali za množice, ampak zate in tebi podobne. [53] Nič drugače, kot so stari pisci neukim ljudem z ugankami in pregrinjali bajk preprečili uvid v misterije, smo jim tudi mi naše jedi po navadi priskutili z nekoliko grenkejšo skorjo besed, saj bi jih sicer zagotovo oskrunili. ${ }^{37}$ [54] Tudi tisti, ki hočejo skriti zaklade, jih, če jih ne morejo spraviti na varno mesto, po navadi prekrijejo s smetmi ali gruščem, da jih mimoidoči ne najdejo, razen tisti, za katere so sami presodili, da so tega daru vredni. [55] Podobno si filozofi prizadevajo, da bi svoje zadeve zakrili pred preprostim ljudstvom; zanje se namreč ne bi spodobilo, da bi jih to hvalilo ali razumelo in zaradi tega se ne more spodobiti, da njihovi spisi vsebujejo karkoli teatralnega, preprostega ali aplavza vrednega, saj bi se naposled zdelo, da se prilagajajo okusu ljudstva. [56] Želiš, da ponazorim, kakšna zamisel tiči za našim načinom izražanja? [57] Gre za popolnoma enako reč kot pri Alkibiadovih Silenih..$^{38}$ [58] Obstajali so namreč kipi tega bitja, ki so imeli grob, grd in ostuden obraz, medtem ko je njihova notranjost bila polna gem in drugih redkih ter dragocenih predmetov. [59] Tako si, če si jih gledal od zunaj, videl pošast; če pa si se zazrl v njihovo notranjost, si spoznal, da gre za božanstvo. [6o] »Toda«, porečeš, »ušesa ne prenesejo zdaj ostre, zdaj mehke in zmeraj neskladne teksture; ${ }^{39}$ ne prenesejo barbarskih besed, katerih zven nas skoraj mora navdati z grozo. «40 [61] O občuljivec, nastavljaj ušesa, ko boš v družbi piskačev in plunkarjev. Ko

36 Analogen je opis del Pitagorejcev v: Jamblih, Vita Pythagorica 157.

37 Pogost topos. Glej Makrobij, Somnium Scipionis 1.2.17-1; Boccaccio, Genealogia 15.8; Ficino, In Convivium. 4.2; Poliziano, In Charmidem Platonis Praefatio; Pico, Heptaplus proemij.; Dionizij Areopagit, Cealestis hierarchia 2 (PG 3.133); Jamblih, Vita Pythagorica 104, 162, 227, 245, 247.

38 Platon, Symposium 215a-b, 216d-217a, 221d. Besedna zveza Sileni Alcibiadis je prešla v pregovorno rabo. Uporabljali so jo za poimenovanje ljudi in stvari, ki so grdega videza, a njihova notranjost razkriva izjemno odliko oz. vrednost. O tem piše Erazem Rotterdamski v Adagia 2201, glej tudi Moriae encomium 29. Pico Sokrata v tem pismu vselej omenja kot primer nevšečne, neurejene zunanjosti in izjemne modrosti $(\$ 40, \$ 66, \$ 77)$.

39 Mišljeno je kakofoničo stikanje konzonantov in pretirano nizanje vokalov, zaradi česar je prihajalo do hiatov. Prim. Cicero, De oratore 3.43.171 in Orator 44.150; Kvintilijan, Institutio oratoria 9.4.36-37.

40 Humanistom nista ugajala ne slog ne leksika sholastikov. Motile so jih zlasti neelegantne skovanke, ki jih kritizira že Lorenzo Valla v delih Elegantiae in Retractatio totius dialecticae. 
boš pa s filozofi, pozabi na čute, vrni se vase, v svetišče duha in zavetje uma. [62] Nadeni si tista slavna ušesa Tianskega, s katerimi - ko je bil povsem pozabil na telo - ni poslušal zemeljskega Marsia, ampak nebeškega Apolona, ki je iz božanske kitare izvabljal neizrekljive tone, združene v kozmični napev. ${ }^{41}$ [63] Če boš besede filozofa ocenil s temi ušesi, se ti bodo zdela tako sladka, da bi še Nestorja popadla nevoščljivost. ${ }^{42}$

[64] A pustimo ob strani te vse prevzvišene reči. [65] Zanesljivo moramo mrzkost nadvse ostroumne, a slogovno manj elegantne filozofske razprave prej kot izbranemu okusu pripisati nenavajenosti. [66] Nič drugače ne bi bilo, ko bi koga na Sokratu, ki uči o dobrih navadah, zmotil razvezan čevelj ali razpeta toga in bi bruhal jezo in žolč zaradi površno ostriženega nohta. ${ }^{43}$ [67] Tulij pri filozofu ni iskal govorniške spretnosti, ampak poznavanje snovi in vsestransko učenost. ${ }^{44}$ [68] Tako vešč govorec kakor učenjak sta vedela, da je naša skrb prej tvorjenje misli kot skladanje izraza; da pazimo, da ne bi zašel razum in ne, da se ne bi zapletel jezik; da se posvečamo notranjemu preudarjanju, ne zunanjemu zvenu besed; 45 da je za nas hvalevredno imeti muze $v$ duhu, ne na ustnicah; da pazimo, da naše besede ne bi zvenele ostreje zaradi jeze ali mehkeje zaradi nasladnosti; in naposled, da ne bi bile sprte $\mathrm{z}$ naravno harmonijo, po kateri so uglašene, da sploh zvenijo. ${ }^{46}[69]$ Ko je Platon doumel, da gledališka in pesniška harmonija naravno harmonijo pogosto zrušita, je vse pesnike izgnal iz svoje države, njeno upravljanje pa je zaupal filozofom, ki bi bili prav tako obsojeni na izgon, če bi posnemali izumetničenost

41 Ni jasno, katero delo je Picu služilo za vir pri tej omembi Apolonija iz Tiane, grškega neopitagorejskega filozofa iz 1. stoletja n. š.. V Filostratovem delu Vita Apollonii Thianei ni zaslediti, da bi Apolonij bil sposoben slišati harmonično glasbo nebeških sfer. Mesto spominja na odlomek iz Jambliha, ki to sposobnost pripisuje Pitagori, in mogoče je, da je Pico Tianskega zamenjal s Pitagoro (Jamblih, Vita Pythagorica 65-67). Filostrat sicer navaja govorice, da je Apolonij komuniciral z bogovi - tudi z Apolonom - in da je ta komunikacija predstavljala vir njegovih naukov (Filostrat, Vita Apollonii Thianei 1.1). Marsias je bil satir, ki si je z avlosom drznil na glasbeni dvoboj izzvati Apolona, božanskega igralca na liro. Za zmagovalca je bil proglašen Apolon, ki je nato Marsia privezal na drevo in ga živega odrl. Platon v Državi meni, da sta v polisu uporabni le lira in kitara, avlos pa zavrne kot neprimeren (Platon, Respublica 3.399d-e).Tudi Pitagora in njegovi učenci so po Jamblihovih besedah uporabljali liro, saj je Pitagora menil, da je avlos primeren le za slavja in veselice ter da je za svobodnega človeka nedostojen (Jamblih, Vita Pythagorica 111). Apolonovo liro so pogosto interpretirali kot alegorijo za nebeško harmonijo, nad katero je bdel Apolon sam (glej npr. Boccaccio, Genealogia 5.3).

42 Prim. Homer, Ilias 1.248-49.

43 Prim. Horacij, Sermones 1.3.30-32, Epistulae 1.1.96-97 in 1.1.104.

44 Glej Cicero, De Finibus 1.5.15.

45 Dva nivoja logosa. Pico tukaj vzpostavi antitezo, ki jo z analognimi izrazi v pismu vzpostavi še nekajkrat: misli - izraz, razum - jezik, duh - ustnice v istem paragrafu ter srce - jezik v $\$ \$ 18,119$. Plutarh piše, da je notranji govor Hermesov dar, ki človeku podeljuje notranjo harmonijo in mir, zunanji govor pa je zgolj instrument komunikacije z drugimi (Plutarh, Moralia $777 \mathrm{~b}-\mathrm{d}$ ). Pico je tukaj zagotovo imel v mislih tudi Platona, natančneje Platon, Phaedrus 275d-278e, kjer Sokrat loči med zapisanim govorom in notranjim - v dušo zapisanim - govorom.

46 Koncept notranjega govora oz. preudarjanja, ki človeku zagotavlja notranji mir in harmonijo, je tukaj povezan s pitagorejsko in platonsko teorijo o povezanosti, uglašenosti človeške duše z ureditvijo kozmosa (glej Jamblih Vita Pythagorica 64-66; Platon, Respublica 4.443d-e, Leges 3.689d, Protagoras 326b). 
pesniškega jezika. ${ }^{47}$ [70] Kljub temu je Lukrecij ${ }^{48}$ vztrajal, da je treba resnost vsebine prikriti s slogovno privlačnostjo, čeprav je filozofske razprave same ne potrebujejo, prav kakor grenek pelin sam prežene bolezen, a ga kljub temu sladijo z medom, da bi pretentali brezbrižna otroška leta. ${ }^{49}$ [71] Če si svoja dela pisal za dečke in rajo, o Lukrecij, si to verjetno moral početi; prav gotovo si moral, saj nisi ponujal le pelina, ampak tudi najčistejše strupe. [72] Mi moramo ravnati popolnoma drugače, saj preprostega ljudstva, kot smo povedali že prej, nočemo privabiti, temveč odvrniti, ne ponujamo gnusnega pelina, temveč nektar. [73] A Laktancij bo trdil, da je dovolj dobro znano, da resnica učinkoviteje prodira $\mathrm{v}$ duhove slušateljev, tudi starejših, če se lahko zanaša tako na svojo moč kot na bleščeč jezikovni okras. ${ }^{50}$ [74] Če bi bil, dragi Firmijan, tako dobro seznanjem s svetimi spisi, kot si bil spreten $\mathrm{v}$ namišljenih sporih, ${ }^{51}$ tega ne bi trdil, prav tako pa ne bi nič slabše potrjeval naših naukov, kot si tuje razdiral..$^{52}$ [75] Povej mi, prosim, kaj bolj gane in prepriča kot branje Svetega pisma? [76] Besede Postave, ki so sicer surove in preproste, a tudi žive, navdihnjene, plamteče in izostrene, prodrejo v globine duha ter s svojo čudovito močjo človeka popolnoma spremenijo - ne le ganejo, ne le prepričajo, ${ }^{53}$ ampak prisilijo, pretresejo in popolnoma prevzamejo. ${ }^{54}$ [77] Alkibiad pravi, da ga Periklovi bleščeče izdelani govori ne ganejo, Sokratove gole in preproste besede (doda, da četudi so zoprne) pa ga navdušijo, prepričajo in hočeš nočeš prisilijo, da naredi, kar je zapovedal.55 [78] A kaj bi govoril o jasnih stvareh?! [79] Če slušatelj ni neumen, kaj, razen prevare, naj pričakuje od izlepotičene-

47 Glej Platon, Respublica 2.377a-3.398b, 5.471c-6.502c in 10.605a-6o8b, Leges 3.699b-701c.

48 Lukrecij je v pismu deležen ostre kritike in obtožen kvarnega vpliva na ljudi zaradi pesniške forme svojega dela ter zaradi epikurejstva. Lukrecij 1.936-47.

49 Figura, ki jo uporabi tudi Lukrecij $(1.936-47,4.11-25)$ in izvira iz Platon, Leges 2659 e-66oa, se je uporabljala v zvezi s stilističnim slajenjem in okraševanjem del, ki obravnavajo težavne in resnobne teme. Prim. $\$ 73$ in Kvintilijan, Institutio oratoria 3.1.3-5.

50 Laktancij, Institutiones divinae 1.1 in 3.1. Podobno kot Lukrecij je tudi Laktancij (Lucius Caecilius Firmianus Lactantius, ok. 245-ok. 325) deležen kritike zaradi prepričanja, da je potrebno teološka in filozofska dela pisati v visoko izdelanem, okrašenem slogu, da bi bila lažje berljiva in bolj prepričljiva. V pismu je analogija med njima nakazana s podobno uvedbo njunih imen. Verjetno ju Pico vzporeja tudi zato, ker je Laktancij v svojih Institutiones divinae povzel Lukrecijevo figuro o slajenju grenkega zdravila z medom (Laktancij, Institutiones divinae 5.1). Nanj so se po navadi sklicevali tisti humanisti, ki so zagovarjali združevanje vere z govorniško spretnostjo. Gianfrancesco Pico della Mirandola, Giovannijev nečak, mu je nadel vzdevek Cicero christianus, ki je prešel v splošno rabo. Ohranjena so le njegova krščanska dela, med katerimi je najpomembnejše zgoraj omenjeno Institutiones divinae v sedmih knjigah. Gre za obrambo krščanske doktrine kot skladnega in doslednega sistema. Posebnost dela je, da se Laktancij v njem ne sklicuje na Sveto pismo, temveč na pričevanja poganskih piscev. Krščansko vero je skušal upravičiti bolj z razumom kot avtoriteto, zaradi česar je bil deležen številnih kritik iz vrst kristjanov - očitali so mu slabo teološko podkovanost, a mu hkrati priznavali visoko retorično spretnost pri zavračanju poganske religije.

51 Prim. \$16. Izmišljeni spori so v retorskih šolah predstavljali vajo, v kateri so se učenci skozi zagovarjanje ali nasprotovanje izmišljenemu predmetu spora urili v govorniški veščini.

52 Prim. Hieronim, Epistulae 58.10.

53 Ganiti in prepričati (movere et persuadere) sta tehnična termina retorike, ki predstavljata želeni učinek in cilj govorniškega nastopa.

54 Trditev, izražena $v \$ 76$, je v neposrednem nasprotju $\mathrm{z}$ značilnim humanističnim stališčem, ki ga Pico povzame v $\$ 83$. Prim. $\$ 27$.

55 Glej Platon, Symposium 215c-216b; prim. Apologia 17b-c; Ficino, In Convivium 7.2. 
ga govora? [80] Tri stvari, ki najbolj prepričajo, so zgledno življenje govorca, resničnost vsebine in treznost govora. ${ }^{56}$ [81] Le tako, Laktancij, si bo filozof pridobil zaupanje: če bo dober, če bo govoril resnico in če bo segal po slogu, ki ne priteka iz prijetnih gajev muz, ampak iz srhljive votline, v kateri se skriva resnica, kot je govoril Heraklit. ${ }^{57}$

[82] Toda nekdo bo porekel: »Daj, prijatelj, pustiva prepir in zadevo ponovno pretehtajva: modrost je po sebi nekaj častitega in božanskega in ne potrebuje nikakršnega tujega okrasa; toda čemu ogorčenost, če je okras prisoten? [83] Kdo trdi, da kar je dobro po sebi, z okrasom ne postane še boljše?« [84] Jaz, prijatelj, to trdim v večini primerov. Toliko stvari je namreč, katerih sijaj zastreš in ne okrepiš, če jim karkoli pritakneš. Tako očitno je, da so po svoji naravi v najboljšem stanju, da jih drugače kot na slabše ne moreš spremeniti. [85] Marmorne palače ne boš pleskal. Če bi nanjo nanesel omet, bi ji odvzel sijajnost in lepoto. [86] Nič drugače ni z modrostjo in snovjo, ki jo obravnavajo filozofi: če ju premažeš, ne zasijeta v večjem sijaju, temveč potemnita. [87] Kaj naj še dodam? [88] Ali ni splošno znano, da strupena voščena lepotila lepo lice naredijo grdo? [89] Nasploh velja, da vsak okras to, na čemer pristane, zakrije, na ogled pa postavi, kar prinaša s seboj. [9o] Zatorej, če je osnova boljša od pritaknjene stvari, bo slednja le v škodo in ne v korist. [91] Zaradi tega se filozofija ponuja gola, povsem razkrita, da se vidi vsa njena odličnost. Veseli se biti vsa na ogled in v celoti podvržena presoji, saj ve, da ima to, zaradi česar vsa in v vseh ozirih ugaja. [92] Kolikor je zakriješ, toliko zakriješ njene lepote in za toliko zmanjšaš njeno vrednost. Želi, da jo obravnavamo neokrnjeno in čisto: če bi ji karkoli primešal, bi jo omadeževal, oskrunil in spremenil v nekaj drugega. [93] Stoji na eni sami nedeljivi točki. [94] In zato pri tako resni in pomembni stvari, kjer je hudodelstvo karkoli odvzeti, dodati ali spremeniti, igračkanje s tropi, bahanje $z$ obiljem besed, samovšečno pretiravanje $\mathrm{z}$ metaforami in predrzna izumetničenost niso na mestu.

[95] Odvrnil boš: »Prav, priznamo, ni vaša naloga, da se izražate elegantno, zagotovo pa je vaša dolžnost, ki je ne izpolnjujete, da se vsaj latinsko; da stvar razložite, če že ne z lepimi pa vsaj s pravilnimi besedami. [96] Od vas ne zahtevam uglajenega jezika, a vsaj nizkoten naj ne bo; nočem blagozvenečih besed, vendar tudi kozlovskega meketanja ne. [97] Ni treba, da so

56 Prim. Laktancij, Institutiones divinae 4.23.

57 Heraklit, DK 123: »Narava se rada skriva.«Picov vir je verjetno bil Temistij, Orationes 5.69b, ki Heraklita navaja. Možno je tudi, da je Pico zamenjal Heraklita z Demokritom, ki se mu pripisuje podoben izrek (Demokrit, DK 117; Diogen Laertski 9.72; Cicero, Academica 1.12, Lucullus 32; Laktancij, Institutiones divinae 3.28 in 3.30; Izidor, Origenes 8.6.12). Picov navedek Heraklita je zelo zanimiv, saj je ta v antiki veljal za izredno poetičnega avtorja, čigar izumetničenost je kritiziral celo Lukrecij (1.638-44), ki je pri Picu tarča ostre kritike ravno zaradi poetičnega sloga. Glej tudi Aristotel, Rhetorica. 3.5.1407b. Vsekakor je Pica močno prevzela ideja o skritosti/zakritosti narave in resnice, saj je postala pomembna sestavina njegove dokrtine (in temelj, na katerem je zasnoval svoje delo Heptaplus, poskus alegorične razlage Geneze. Glej Pico, Heptaplus proemij). Potrditev za to idejo je Pico našel tudi v Psalmih (Vulgata, Psalmi 50.8) 
vaše besede pazljivo izbrane, a tudi zanemarjene ne. [98] Ne prosimo, da bi bile posebej všečne, toda tožimo, ker so žaljive.« [99] Že dobro, očitno že prehajaš na našo stran. [10o] Toda, prosim, poglejmo in preverimo, kaj je ta čista in dobra latinščina, katero edino, kot pravite, so filozofi dolžni, a nezmožni, uporabljati. [101] Na primer, pri izreku homo a sole producitur bodo naši namesto producitur uporabili causatur..$^{58}$ [102] Brž boš zaklical: "To ni latinsko«, in do tukaj imaš prav, »ni izrečeno v rimski maniri«, drži kot pribito, »torej ni pravilno!« - v zaključku pa se motiš. [103] Isto bo izrekel Arabec, isto Egipčan; njuna izreka ne bosta v latinščini, a vendar bosta pravilna. [104] Imena stvari namreč določa ali dogovor ali njihova narava..$^{59}$ Če jih določa naključno poimenovanje (to pomeni, da znotraj skupnosti kot pravilna veljajo imena, ki jih skupnost določi na podlagi dogovora), kaj bi lahko preprečilo tem filozofom, ki jih vi zmerjate $\mathrm{z}$ barbari, da bi se dogovorili in zedinili glede jezikovne norme, ki zanje ne bi bila nič manj sveta, kot je rimska norma sveta za vas? [105] Če je torej poimenovanje stvari povsem arbitrarno, potem ni nobenega razloga več, da bi svoje poimenovanje imenovali pravilno, ono pa nepravilno; in če tega kljub temu nočete počastiti z rimskim imenom, ga imenujte pa galsko, britansko, hispansko ali (kot je navada množice) pariško. ${ }^{60}$ [106] Ko bodo govorili z vami, se jim boste večinoma posmehovali, večine ne boste razumeli. [107] In ko boste sami prišli do besede, se

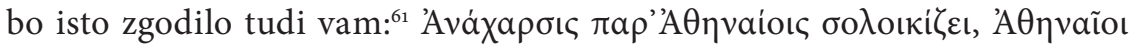
$\delta \grave{\varepsilon} \pi \alpha \rho a ̀ ~ \Sigma \kappa u ́ \theta a ı \varsigma,{ }^{62}$ kar pomeni, Anaharzis ${ }^{63}$ med Atenci naredi solecizem, ${ }^{64}$ Atenci pa med Skiti. [108] In če je pravilnost imen odvisna od narave stvari, ali naj za mnenje o njej vprašamo retorje ali raje filozofe, ki so edini odkrili in raziskali naravo vseh stvari? ${ }^{65}$ [109] Morda to, kar ušesa zavračajo kot nekoliko rezko, razum sprejema kot stvarem sorodnejše. [110] »Toda kaj

58 V klasični latinščini je glagol causari deponentnik, v srednjeveški latinščini pa ima pasiven pomen.

59 Ali poimenovanje stvari temelji na dogovoru ali izvira iz narave stvari, se je spraševal že Platon v Kratilu. Prim. Gelij 10.4.1-3. Pico se v pismu glede tega vprašanja ne opredeli, temveč sholastiku v usta položi zagovor, ki v obzir vzame obe teoriji.

60 T.i. pariški slog je bil slog mislecev pariške univerze in sholastikov nasploh. Gre za neke vrste tehnično latinščino sholastičnih filozofskih razprav. V svojih 900 tezah in v Apologiji se je poslužuje tudi Pico.

61 Prim. Palton, Gorgias 484d-e.

62 Stavek se ne pojavi v nobenem drugem delu, zato ni znano, ali ga je Pico dobesedno citiral ali ga je pod vplivom kakšnega vira tvoril sam. Pri Grkih je bila skitska neotesanost in surovost pregovorna. O tem Erazem Rotterdamski, Adagia 2.3.35.

63 Anaharzis, skitski filozof, je živel približno v času Solona. Kar se tiče pregovorne skitske surovosti, je predstavljal izjemo (Herodot 4.46 in 76). Diogen Laertski (1.41 in 101-105) ga uvršča med sedem modrecev. Da bi zadostil svoji veliki želji po znanju, je veliko potoval, med drugim tudi v Grčijo. Umrl naj bi pod puščico svojega brata, skitskega kralja, ko je skušal v Skitijo uvesti grški misterijski kult oz. zaradi svojega filhelenizma (Herodot 4.76; Diogen Laertski 1.103). V antiki so pod njegovim imenom krožila pisma, enega od njih citira Cicero, Tusculanae disputationes 5.90. Nekaj njegovih sentenc se je ohranilo tudi preko drugih avtorjev: Aristotel, Ethica Nicomachea 10.6; Atenaj 10.437 in 445; Elijan, Varia historia 2.41.

64 Jezikovna napaka, predvsem v izgovoru ali skladnji. Imenuje se po prebivalcih kolonije Soli na Kilikiji, ki so pod tujim vplivom pačili grščino.

65 Prim. Platon, Cratylus 389a-39oe; o poimenovanju stvari po naravi prav tam 396a-421c. 
jim je bilo treba na novo izumljati jezik in opuščati čisto latinščino, če so se vendar med latince rodili?« [111] Niso mogli, dragi Ermolao, medtem ko so zazrti v nebo motrili zakonitosti usode, znamenja prihodnjih dogodkov in ureditev kozmosa ter medtem ko so s pogledom, uprtim v tvarino, opazovali menjavanje rojstev in smrti, moč elementov ter kakovost spojin; niso mogli, povem ti, istočasno gledati na značilnosti, pravila in zakonitosti rimskega jezika v delih Cicerona, Plinija in Apuleja. ${ }^{66}$ [112] Zanimalo jih je, kaj je lastno in tuje naravi, medtem ko se za to, kaj je lastno in tuje Rimljanom, več niso menili.

[113] A naj ti nekoliko popustim: priznam, da sta besedna spretnost in modrost v vzajemnem odnosu. [114] Filozofi se z modrostjo vedno bolj oddaljujejo od besedne spretnosti, zgodovinarji, retorji in pesniki pa se - nad čemer toži Filostrat - $\mathrm{z}$ besedno spretnostjo vedno bolj oddaljujejo od modrosti. ${ }^{67}[115]$ Niti najmanj ne dvomiš, da bodo slednji živeli v večni slavi, prvi pa zaničevani in v sramoti. [116] Pazi, kaj govoriš; Cicero je bolj naklonjen redkobesedni modrosti kakor neumni jezičnosti. ${ }^{68}$ [117] Pri denarju nas ne zanima, kako so novci kovani, temveč iz katere kovine so. ${ }^{69}$ [118] Ni ga človeka, ki ne bi raje imel zlatnika $\mathrm{z}$ znamenjem Tevtonov ${ }^{70}$ kot ponarejenega novca $z$ rimskim pečatom. [119] Greši, kdor ločuje srce in jezik; ${ }^{71}$ toda ali ni ta, kogar je le jezik in prav nič srca, kot pravi Katon, čisti mrtvaški glosar? ${ }^{72}$ [120] Brez jezika lahko živimo, morda ne polno, a vendar; brez srca pa nikakor ne moremo. ${ }^{73}$ [121] Kdor ni vajen bolj prefinjene jezikovne umetnosti, ni omikan človek; kdor ni seznanjen s filozofijo, sploh ni človek. [122] Koristi lahko že najbolj jecljava modrost; nespametna besedna spretnost pa kot meč v rokah norca lahko le škoduje. ${ }^{74}$ [123] »Torej«, porečeš, »tudi kipe cenimo zaradi materiala, iz katerega so narejeni in ne zaradi lepih oblik; in če bi Hojril opeval iste dogodke kot Homer in Mevij iste kot Vergilij, bi iz tega sledilo,

66 Prim. Avguštin, Confessiones 1.18.

67 Filostrat, Vitae sophistarum 1.481 in 484; glej tudi Cicero, De oratore 3.16 in 19.

68 Cicero, De oratore 3.35.

69 Denar kot metafora za jezik, besede. Prim. Apulej, Apologia 38; Kvintilijan, Institutio oratoria 1.6.3.; Barbaro, Epistolae 10 (uvodno pismo k Temistiju, naslovnik Giorgio Merula).

70 Tako srednjeveške filozofe poimenuje Barbaro v pismu Picu z dne 5. aprila 1985 (Barbaro, Epistolae 68). Prim. Poliziano, Praefatio in Suetonium, o nekem srednjeveškem latinskem prevodu Aristotela: »Primerjal sem grškega Aristotela s tevtonskim, to je besedne umetnosti izredno veščega s popolnoma bebljavim....

71 Prim. Cicero, De oratore 3.16.

72 Za Katonovo izjavo glej Gelij 18.7. Pico si je tukaj dovolil priredbo tedaj dobro poznanega izvirnika, s čimer je dosegel, da je citat učinkoval komično. Pri Geliju namreč gramatik Domicij s Katonovimi besedami izreka kritiko filozofu Favorinu. Epizodo so radi povzemali humanisti, ki so kritično vrednotili sholastično filozofijo in jo kritizirali zaradi prevelikega dialektičnega dlakocepstva, kar naj bi jo oddaljevalo od realnega življenja, predvsem pa od etike, za humaniste edine prave veje filozofije - glej npr. Petrarca, Rerum memorandarum libri 3.47.

73 Odgovor na Georgij Trapezuntski, Rhetorica 1: „Ker če vsi menijo, da je največja hiba biti nem (očitno je namreč, da je ta, ki ne zna govoriti, povsem brez človeške omike), gotovo isto velja tudi za slabo jezikovno izražanje. To je resnično najbližje največji hibi in popolni prikrajšanosti za omiko.«

74 Prim. Cicero, De inventione 1.1. 
da se v obeh primerih prvega in drugega pesnika enako ceni.«75 [124] Mar ne vidiš, da tukaj ni podobnosti? [125] Tudi mi trdimo, da je treba dela soditi po obliki, ne po snovi (dela namreč določa oblika): vendar nekaj je oblika, zaradi katere nekoga štejemo med filozofe, in nekaj drugega oblika, ki nekoga uvršča med pesnike. [126] Lukrecij je pisal o naravi, o Bogu, o previdnosti; o istih stvareh je pisal tudi marsikdo od nas, na primer Janez Skot, ki je pisal v verzih, da bi dajal videz nesposobnosti. ${ }^{76}[127]$ Lukrecij pravi, da počelo stvari predstavljajo atomi in vakuum, da ima Bog telo in da naših zadev ne pozna ter da se vse vrši nenačrtno, zaradi naključnih trkov telesc; ${ }^{77}$ in vse to pove $\mathrm{v}$ pravilni in elegantni latinščini. [128] Janez pravi, da vse stvari v naravi tvorita forma in materija, da je Bog ločen um, ki vse ve in na vse gleda in da se, čeprav vidi in uravnava prav vse, tudi najnižje stvari, nikoli niti najmanj ne oddalji od svojega miru, temveč, kot pravimo, med spuščanjem ne sestopa. ${ }^{78}$ [129] In to pove na neokusen ter surov način, $\mathrm{z}$ besedami, ki niso latinske. [13o] Povej mi, prosim, ali obstaja kakšen dvom, kdo od njiju je boljši pesnik in kdo boljši filozof. [131] Povsem na dlani je, da Skot toliko pravilneje filozofira, kolikor lepše Lukrecij pesni. [132] Toda poglej, v čem se razlikujeta: prvi ima nespreten jezik, ${ }^{79}$ drugi nespameten um. [133] Prvi ne pozna pravil slovničarjev, da ne omenjam pesnikov; drugi ne pozna zakonov Boga in narave. [134] Prvi, nezaslišano nespreten $\mathrm{z}$ besedami, ${ }^{80}$ zaznava in razume to, česar se $\mathrm{z}$ besedami ne da hvalilti $\mathrm{v}$ zadostni meri; drugi, nadvse spreten $\mathrm{v}$ izražanju, izreka nezaslišane reči.»

[135] Morda bi ti barbari, najdražji Ermolao, v svojo obrambo navedli te argumente, morda pa celo, glede na njihovo ostroumnost, še veliko boljše. [136] Sam se z njihovimi mislimi ne strinjam popolnoma, niti ne menim, da bi se moral strinjati s komerkoli od njih, pa čeprav je plemenitega in svobodomiselnega duha. [137] Toda to snov, za katero bi lahko trdili, da je na tako slabem glasu kakor tisti, ki hvalijo kvartano, sem rade volje obravnaval in sicer tako da bi preizkusil svoje umske sposobnosti kakor z namenom, da bi iz tebe izvabil zagovor govorniške spretnosti, kot tisti slavni Glavkon, ki pri Platonu hvali krivičnost, vendar ne iz prepričanja, temveč da bi Sokrata pripravil k hvali pravičnosti. In da bi te še bolj podžgal, sem si pri obravnavi dovolil malo

75 Hojril je bil epik iz Jazosa v Kariji. V antiki je veljal za model slabega pesnika. Ustvarjal je v službi Aleksandra Velikega, po anekdoti naj bi za vsak verz prejel zlatnik: Horacij, Epode 2.1.232-34, Ars Poetica 357-58; Kurcij Ruf 8.5.8. Hojrila in Homerja je primerjal že Aristotel (Aristotel, Topica 8.1.157a). Mevij je bil pesnik avgustejske dobe. Kot Vergilijev kritik si je nakopal sovraštvo pesnikov Mecenatovega kroga: Vergilij, Eclogae 3.90; Horacij, Epode 10.

76 Primerjava Lukrecija, predstavnika visokega pesniškega sloga, in Skota, predstavnika barbarskih filozofov, ki se ga je prijel vzdevek doctor subtilis.

77 Strnjen povzetek nekaterih glavnih epikurejskih naukov, ki jih Lukrecij opiše v svoji pesnitvi De rerum natura: atomi in vakuum kot počeli kozmosa (Lukrecij 1), značaj bogov in njihovo nevmešavanje v človeške zadeve (prav tam 5.91-379), slučajni trki atomov kot izvor vseh stvari (prav $\operatorname{tam} 2$ ).

78 Glej Plotin 4.3.12, 4.4.16 in 4.7.13.

79 Prim. Boccaccio, De casibus 6.13.

8o Prim. Rhetorica ad Herennium 2.11. 
več predrznosti, čeprav sta se moj razum in narava nekoliko upirala. ${ }^{81}$ Če bi menil, da je govorniško spretnost treba puščati vnemar ali jo zapostavljati na račun barbarov, se od njih ne bi odvrnil, kot sem nedavno storil, in se skoraj ves posvetil grški književnosti ter tvojemu Temistiju, ki ga ni moč zadostno hvaliti. $^{82}$ [138] Čeravno (odkrito bom povedal, kaj mislim) ${ }^{83}$ se mi prav gabijo nekateri slovničarčki, ${ }^{84}$ ki se tako bahajo, tako hvalisajo in tako nosijo, ker so našli etimologijo dveh besed, in mislijo, da filozofi v primerjavi z njimi niso vredni počenega groša. [139] »Zavračamo, « pravijo, »to vašo filozofijo!« Je to kaj čudnega? [140] Tudi psi zavračajo falernca. ${ }^{85}$ [141] Naj na tem mestu pismo končam z naslednjim zaključkom: če si ti zloglasni barbari s samim poznavanjem stvari zaslužijo neko čast in slavo, potem ni enostavno napovedati, katero mesto in kakšno hvalo si boš prisvojil ti, najspretnejši govornik med filo-

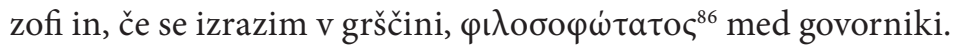

V Firencah, 3. junij 1485

81 Prim. Gelij 17.12.1-3. Glavkon hvali krivičnost, da bi spodbudil Sokratov odgovor: Platon, Respublica 2.358b-362c. Nedvomno gre za poklon Barbaru, saj tradicija veleva, da je izzivalec, ki se poslužuje tega sredstva, vselej mlajši sogovornik, ki se trudi spodbuditi starejšega, izkušenejšega in modrejšega, da bi zavzel pravilno stališče in ga zagovarjal z vso težo svoje avtoritete.

82 Pico se je v prvi polovici osemdesetih na spodbudo Barbara posvetil temeljitejšemu študiju grščine in grške filozofije. K temu glej Barbaro, Epistolae 68 (Picu, 5. april 1485): „Spodbujal sem te k tej [grški] učenosti, da bi ti postala tako domača kot latinska, a ostrog nisem potreboval ... Vem, da se tega zavedaš: da se dela nikogar, ki ni poznal grškega jezika in učenosti, niso prav dolgo ohranila.« V istih letih je Pico vneto preučeval Barbarov prevod Temistija, ki je bil natisnjen 1. 1481. V pismu Barbaru, datiranem na 6. december 1486, je zapisal: »...in največji del svojih noči prebedim ob tvojem Temistiju.« Prevodu je namenil nemalo hvale, npr. v nekem nedatiranem pismu Barbaru je o njem napisal: „Ljubi Bog, koliko učenosti, kakšno bogastvo besed, kakšna jasnost, kako prefinjen slog."

83 Prim. Cicero, De oratore 2.90.

84 V izvirniku grammatistae. Pejorativno. Glej Svetonij, De grammaticis 4.

85 Namiguje na izraz caninum prandium, ki ga razloži Gelij 13.31.16; glej tudi Erazem Rotterdamski, Adagia 1.10.39. Falernsko vino je v antičnem Rimu slovelo po svoji pregovorni odličnosti.

86 Prim. npr. Platon, Respublica 6.498a. 